Palamarchuk Kateryna

PhD in Arts, Associate Professor

Department of Foreign Languages in

Mathematical Faculties

Of Kyiv National Taras Shevchenko University

ORCID 0000-0002-2287-5495

kate.palamarchuk@gmail.com

Lyashenko Larysa

Candidate of Pedagogical Sciences,

Associate Professor

Department of Foreign Languages

Natural Sciences Faculties,

Taras Shevchenko Kyiv National University

ORCID 0000-0002-6860-8552

larnik1881@gmail.com

\title{
THE PROBLEM OF NATIONAL IDENTITY IN THE ECCLESIASTICAL CATHOLIC CULTURE OF AUSTRIA OF THE XVIII CENTURY
}

The purpose of the article is to consider the development of the ecclesiastical culture of Catholic countries (Austria, Germany, Poland) on the example of Austria of the XVIII century. It is important to point out and analyze the specific features of the Austrian national culture and its uniqueness in the hierarchical system of the world religious cultures. Methodology. To achieve this purpose, the following logical and semantic research methods were used: historical-dialectical (for the analysis of historical and cultural processes in Austria of the mentioned period), literary studies (for the consideration of church liturgical works) and a method of theoretical generalization that allows us to consider the Austrian church art in the context of the ecclesiastical culture. Scientific novelty. Despite the existence of a number of studies devoted to Catholic culture in the field of art and culture, in Ukrainian science this topic did not become the subject of a comprehensive study. The connection between the European and Ukrainian ecclesiastical traditions is important for understanding the Catholic national culture and art. This led to the choice of the topic of this work. Conclusions. A specific feature of the Catholic ecclesiastical culture is its confessional differentiation. It was formed under the influence of the historical and geographical conditions of the society. The Austrian national component in the ecclesiastical culture of Catholic countries as a system of aesthetic national values is closely linked with the establishment and preservation of Catholic national traditions. This means that Austrian church art and ecclesiastical culture are important components of the hierarchical system of religious culture, which main value lies in the socioreproductive creative activity of artists in the sphere of consciousness. This in its turn is closely related to the transcendent sphere of activity, as well as to the high artistic level and artists' skills. That's why, like in other national cultures, the ecclesiastical culture of Austria has a national-religious character.

Key words: Catholic church; national identity; religious character; ecclesiastical culture; Austrian reforms; secularization; Baroque.

Паламарчук Катерина Миколаївна, кандидат мистецтвознавства, доцент кафредри іноземних мов математичних фракультетів Київського національного університету ім. Т. Шевченка; Ляшенко Лариса Миколаївна, кандидат педагогічних наук, доцент кафредри іноземних мов математичних фракультетів Київського національного університету ім.Т.Шевченка

\section{Проблема національної індентичності в духовній католицькій культурі Австрії XVIII століття}

Метою статті є розгляl розвитге духовної культури католицьких країн (Австрія, Німеччина, Польща) на прикладі Австрії XVIII століття. Важливо відзначити та проаналізувати особливі риси австрійської національної культури та ї̈ унікальність в ієрархічній системі світових релігійних культур. Методологія. Для досягнення цієї мети були використані наступні логічні та семантичні методи дослідження: історико-діалектичний (для аналізу історично-культурних процесів, що відбувалися в Австрії означеного періоду), літературознавчий (для розгляду церковно-літургічних творів) та метод теоретичного узагальнення, який дозволяє розглянути церковне мистецтво Австрії в контексті духовної культури. Наукова новизна. Попри наявність низки досліджень, присвячених католицькій культурі у мистецтвознавчому та культурологічному ракурсах, в українській науці ця тема не ставала предметом комплексного дослідження. Зв'язок європейської та української духовних традицій є важливим для розуміння католицької національної культури та мистецтва. Це зумовило вибір теми цієї роботи. Висновки. Особливою ознакою католицької духовної культури є ії конфесійна диференційованість. Ця особливість була сформована під впливом історикогеографічних умов життя суспільства. Австрійський національний компонент в духовній культурі католицьких країн як системи естетичних національних цінностей тісно пов'язаний із встановленням і збереженням католицьких національних традицій, оскільки австрійське церковне мистецтво та духовна культура є важливими компонентами ієрархічної системи релігійної культури, головна цінність якої полягає в соціально-репродуктивній творчій діяльності митців в сфері свідомості, що в свою чергу тісно пов'язане із трансцедентною сферою діяльності, а також з високим художнім рівнем майстерності митців. Саме тому, як і в інших національних культурах, духовна культура Австрії має національно-релігійний характер.

Ключові слова: католицька церква; національна індентичність; релігійний характер; духовна культура; австрійські реформи; секуляризація; Бароко.

Паламарчук Екатерина Николаевна, кандидат искусствоведения, доцент кафедры иностранных языков математических фракультетов Киевского национального университета им. Т. Шевченко; Ляшенко Лариса Николаевна, кандидат педагогических наук, доцент кафедры иностранных языков математических факультетов Киевского национального университета им. Т. Шевченко

Проблема национальной индентичности в духовной католической культуре Австрии XVIII столетия

Целью статьи является рассмотрение развития духовной культуры католических стран (Австрия, Германия, Польша) в XVIII веке. Важно отметить и проанализировать особые черты австрийской национальной культуры и ее уникальность в иерархической системе мировых религиозных культур которая относится к сокровищнице мировых культур. Методология. Для

(c) Palamarchuk K., 2019

(C) Lyashenko L., 2019 
достижения этой цели были использованы следующие логичные и семантические методы исследования: историкодиалектический (для анализа историко-культурных процессов, происходивших в Австрии указанного периода), литературоведческий (для рассмотрения церковно-литургических произведений) и метод теоретического обобщения, который позволяет рассматривать церковное искусство Австрии в контексте духовной культуры. Научная новизна. Несмотря на наличие ряда исследований, посвященных католической культуре в искусствоведческом и культурологическом ракурсах, в украинской науке эта тема не становилась предметом комплексного исследования. Связь европейской и украинской духовных традиций является важной для понимания католической национальной культуры и искусства. Это и обусловило выбор темы этой работы. Выводы. Особым признаком католической духовной культуры является ее конфессиональная дифференцированность. Эта особенность была сформирована под влиянием историко-географических условий жизни общества. Австрийский национальный компонент в духовной культуре католических стран как системы эстетических национальных ценностей тесно связан с установлением и сохранением католических национальных традиций, так как австрийское церковное искусство и духовная культура являются важными компонентами иерархической системы религиозной культуры, главная ценность которой заключается в социально-репродуктивной творческой деятельности художников в сфере сознания. Это в свою очередь тесно связано с трансцедентной сферой деятельности, а также с высоким художественным уровнем и мастерства художников. Именно поэтому, как и в других национальных культурах, духовная культура Австрии имеет национально-религиозный характер.

Ключевые слова: католическая церковь; национальная индентичность; религиозный характер; духовная культура; австрийские реформы; секуляризация; Барокко.

Introduction. Sociocultural field of Europe of the late XX-early XXI century is defined by changes in social and public status of religion, increasing the impact on art, lifestyle and morality. Religion means preserving of national and spiritual values of the people and an important part of the ecclesiastical culture; that's why cultural research takes the problem of correlation between culture and religion.

The main part. The Catholic Church and culture are ideologically interrelated, as the cultural heritage of the people is the criterion of its national identity. Many researchers

(A. Kartaschev, A. Richynsky and others) believe that culture has always had and now has a national, individually-ethnic form and content; only national culture is able to make a contribution to the treasury of world cultures. [4, 14]

Myhailo Hrushevsky, historian, social and political statesman, develops the Ukrainian idea, including the impact of national origin on the religion, in the context of the European cultural tradition. M. Hrushevsky wrote in his time about resolving the "eternal" problem of relations with international and national, about the folk poetry on the theme of Mary at the cross, recorded in Volhynia. The scientist noted: "Having catholic parallels, west slavic songs about the blessed Virgin Mary in Ukrainian musical versions, obviously, come out from the song about the widow, who is searching for her son. Our Mater dolorosa is a variant of the mourning widow in general". [2]

The history also proves that each nation, each ethnos gave birth to their own system of beliefs, their culture, which was an integral part of an interwoven religion. The uniqueness of national cultures largely depends on the peculiarities of the vision of the world, the creation of national images of peoples. Therefore, modern researchers are trying to understand such phenomena as religion and culture, to understand the specific features of the national character and the language, the national soul that have spawned culture of people, religion and language.

The spiritual life of the people is always a reflection of ecclesiastical art, that in the system of national aesthetic values, defined by traditions of people.

The correlation between religious and national in the life of the people is reflected in the works of the famous Ukrainian public figure Arsen Richynsky (1892-1956), who is the author of the collections of ecclesiastical chants for rural choirs under the title "The popular singing in Ukrainian church" to facilitate religious worship of the national language. A. Richynsky gave his vision of the combination of church and the national, where the outer church was understood to be as an expression of everyday diversity, an expression of religious thought according to the features of the national psyche and national consciousness. These ideas are reflected in the religious-national arts and culture. [11, 12]

The national features of religions are not formed under the influence of some peculiarities of their beliefs or worship, but are caused by predominantly concrete historical and geographical conditions of the lives of those peoples, among which they are arisen or spread, as well as the specifics of national spirituality.

The national ecclesiastical culture is characterized by a creative form of its life on obtaining social genesis. The combined force of the national ecclesiastical culture is accumulated in the interpersonal space of public communication and it makes an important part of this process.

Therefore, the recognition of national identity in ecclesiastical culture means finding a future model of culture, determination of its place and role in the modern world. International dialogue and cooperation have become the norm for the ecclesiastical culture of catholic countries. Taking into account the experience and fate of different christian churches, a return to the classical cultural heritage, exe $r$ cising its reappraisal of use in social practice have defined a new worldview - multi-cultural basis of Catholic cultural tradition.

The Catholic culture occupies one of the leading places in the huge variety of christian cultures. During the New time, since the XV - XVI centuries there has been clearly expressed the tendency of reducing the influence of religion in public life and in the life of the individual. The process of secularization covers the release of various spheres of public life from the control of the clergy as a social group and the church as an institution. 
Until the XIX century in all existing societies religion served as a basis for the forming of outlooks and culture. However, the society of that time has a little tendency to develop a world view, independent from the religious symbols and myths.

As a result of a long historical process all spheres of social life have been separated from religiously implied style of society's life, with its culture, built on a religious basis. Nevertheless, at that time, the religion itself turned into the only sphere of society life, whereas previously it was a unifying force and existed next to the art, science and philosophy.

The Austrian national culture as one of the components of the European culture of peoples was a reflection of secular and religious life of the society of above mentioned era. The Austrian Church of the second half of the XVIII century was closely connected with the policy of the State, the cause of which was a new wave of secularization. In its turn this phenomenon was due to the strengthening of the Enlightened absolutism.

The monarchs, who carried out this policy, portrayed their Government as a Union of Kings and philosophers. Its content was the destruction or conversion of the "top" of the most outdated feudal orders, i.e. in the idea of secular state, in attempt of the absolutism to put secular central power above all.

Following the views established by the tradition, the Enlightened absolutism has brought new understanding of the state and public authorities which fully enjoyed their rights and responsibilities.

The Habsburg dynasty has always remained at the world political arena and was famous for bravery and entrepreneurship. They are considered to be the real founders of the Austrian monarchy as a great powerful state. Habsburg ancestry can be traced back to the middle of the $\mathrm{X}$ century when in Argau lived their first known ancestor - Guntram the Rich. This dynasty sought to combine "crushed" monarchy, relying on the principle of single religion. So Habsburgs invariably have acted exactly as the defenders of the Catholic Church. In its turn the confession solidarity provided Austria with the help of Spain and Rome.

The historical period which is considered in this paper is also one of the most glorious pages of the Habsburg dynasty. This period in the Austrian life of the XVIII century is considered as the reigning of two monarchs: Maria Theresa (reigned in 1740-1780) and her son Joseph II http://www.microsofttranslator.com/bv.aspx?from=uk\&to=en\&a=http\%3A\%2F\%2F65.55.108.4\%2Fbvsandbo x.aspx\%3F\%26lo\%3DSS\%26dl\%3Duk\%26from\%3Duk\%26to\%3Den\%23_ftn3(solely reigned in 1780-1790). Economic and political weakness of the Habsburg monarchy which appeared in particular through numerous wars in the middle of the XVIII century forced the Austrian absolute Government of Maria Theresa to embark on the path of economic and administrative reforms. According to the researchers, her son Joseph II was more radically minded reformer. He broke away with the policy of his predecessors and made a brave attempt to radical transformation of the entire system of Austria in the spirit of the philosophy of the XVIII century. $[5,118]$

Very important for Austria were judicial reforms. So litigations were proclaimed exclusively for the prerogative of Government.

Reforms were carried in the sphere of education too. In the XVIII century the importance of education was recognized as an axiom. The Empress Maria-Theresa considered the Austrian school system as exemplary; in her resolution of 280ctober, 1770 she insisted: "the School will remain forever the governmental affair" ("einpoliticum"). Due to the progressive activity of Maria Theresa's Minister of Education - Gerard van Sviten- the education system has largely been changed.In a definite period of the administrative structure of the school was governed by the Court Commission; previleged noble schools were closed. However the number of vocational schools has been increased in five times.

It is also important that in the second half of the XVIII century in Austria dominated the "Latin schools" where all subjects were taught in Latin. In all cities and villages "trivial school" ("Trivial-Schulen") were founded, in which three subjects: reading, letter and elementary counting were taught. At this time there were also the "normal schools" ("Normal-Schulen") which performed functions of teaching seminaries. There existed the Austrian "high school" ("Haupt-Schulen") too. At the end of Maria Theresa's reigning in Austria there were 15 "normal", 83 "main", 47 women's schools and 3848 "trivial" (vocational schools) in which more than 200000 students studied.

The University of Vienna during the reigning of Empress Maria Theresa was the newest educational institution where at first the question about the serious study of the natural sciences arose. In the second half of the XVIII century there were philosophical, medical, protestants-theological and Catholic-theological faculties. As in the other educational establishments which belonged to the Church, the main subjects continued to be theology, philosophy, law, Latin and Greek. Interesting is the fact that in 1778 in Austria the representatives of other confessions were allowed to get the degree of Doctor. According to modern scholars of the history of Austria, the aim of this important event was distraction of young scientists-theologians from scholastica, contributing to the salvation of souls. It was carried out for the benefit of the valid Government. At the end of the XVIII century studying of Church law was moved from the Theological Faculty to Law Faculty, which could testify to the benefits of secular power over the spiritual one. Moreover in 1847, after several fruitful attempts, the Austrian Academy of Sciences was founded. Due to the reforms in high schools and universities arose a question about the serious study of the natural-historical subjects for the first time. [14] 
The reforms which took place in the Austrian society (and the State as a whole), were concerned with the Church policy: they can rightly be considered reforms of the Catholic Church. [1]

One of the peculiarities of the ecclesiastical art of that period naturally was its clear functional direction - formation of a positive atmosphere in parishes with the purpose of expansion of influence. Baroque style became popular and widely used during Counter-Reformation in Temple architecture (and not only), which differed from the particular splendor (structure Jesuits).

The artistic style of Baroque, originated in Italy, has spread in Spain, Portugal, France, Flanders, then in Germany, Austria and England. Baroque covered various areas of spiritual and cultural life: architecture, music, painting, literature, decorative art, philosophy etc. In the Baroque epoch the impact of the Church and State on the development of music was extremely great. But at the same time is a well known fact that the fate of many composers and their status greatly depended on the commitment and attitude to the music of the court where they served. The composers-musicians looked for places in the cities or in courts where their music was popularized and flourished under the patronage of noble personality.

In architecture, fine and decorative art the Baroque style was one of the major stylistic tendencies since the late $\mathrm{XVI}$ to middle of the XVIII centuries. The Baroque style was recognized in the era of intensive development of nations and national states (mainly the absolute monarchies), the flourishing of manufacture production and at the same time strengthening of the feudal Catholic reaction. The Baroque with its brightness and charm is closely related to the monarchy, the aristocracy and the Church, because at first itwas intended to glorify and promote their power. However, this style reflected the new ideas about the unity, infinity and diversity of the world, about its dramatic complexity, eternal variability, interest in the environment, to the natural phenomena. Having rejected inherited from the Renaissance culture of images about harmony and strict laws of existence of the unlimited abilities of human, his will and mind, the aesthetics of Baroque style was created on the contrast of the person and the world, ideal and sensual beginnings, mind and power of irrational forces. [5]

The Austrian art of the XVIII-century (more than Italian and French) was associated with the strengthening of its political situation among European countries and above all Germany. After the loss of the real power of the Holy Roman Empire namely Austria became the successor which is already in the XVI century to the Habsburg lands annexed the Czech Republic, Hungary, Silesia, part of Polish, Western Ukrainian and Italian lands. The suppression of national-liberation movement at these lands and the victory over the Turkish Ottoman Empire made Austria in the XVIII century one of the strongest and most influential European powers. All these was reflected in the dynamic development of the country's capital - Vienna. So the architectural view of the city mainly determined the Baroque buildings of the XVIII century: residences, palaces and churches.

At the beginning of the XVIII century in Austrian art especially significant was notable the Italian influence. When in the past appeared the Turkish threat in the cities of Empire of Gabsburg the intensive construction was begun. Invited in a greater way from Italy masters taught the local designers and builders of churches and palaces. It should be noted that the architects did not only imitate samples of Italian architecture but also tried to create the Austrian national traditions in art. Many masterpieces of that time belong to the best examples of Austrian architecture.

The Baroque style found also its bright and appropriate representation in paintings, graphics and sculptures. In the Catholic cathedrals paintings evoke the feeling of staying in the world of sacral relics and higher content in parishioners' hearts. Everywhere in the cathedrals were distributed huge altar paintings in which various biblical scenes were depicted. $[13,174]$

The Catholic Ausrtian culture in the XVIII century was religious in content and reflected the life of the society in the epoch of the Enlightened absolutism. The church life was closely connected with the Catholic religious creativity of artists, embodied through the prism of Baroque traditions.

Conclusions. A specific feature of the Catholic ecclesiastical culture is its confessional differentiation. It was formed under the influence of the historical and geographical conditions of the society. The Austrian national component in the ecclesiastical culture of Catholic countries as a system of aesthetic national values is closely linked with the establishment and preservation of Catholic national traditions. This means that Austrian church art and ecclesiastical culture are important components of the hierarchical system of religious culture, which main value lies in the socio-reproductive creative activity of artists in the sphere of consciousness. This in its turn is closely related to the transcendent sphere of activity, as well as to the high artistic level and artists' skills. That's why, like in other national cultures, the ecclesiastical culture of Austria has a national-religious character.

\section{תimepamypa}

1. Винтер Э. Иозефинизм и современность. Вопросы истории религии и атеизма. 1964. № 12. С. 72-80.

2. Грушевський М. С. Історія української літератури: в 6 т. Київ, 1994. Т. 4. 320 с.

3. Жаловага А. С. Антропологічна природа християнства: монографія. Київ, 2008. 288 с.

4. Карташев А.В. Церковь и национальность. Путь. 1943. № 44. С. 3-14.

5. Митрофранов П.П. История Австрии с древнейших времен до 1792 г. Москва, 2003. 156 с.

6. Неретина С. С., Огурцов А.П. Время культуры. СПб., 2000. 344 с.

7. Паламарчук К. М. Католицьке церковне мистецтво Австрії XVIII - XIX століть: стильові тенденції. Мистецтвознавчі записки. 2001. № 20. С. 328-355. 
8. Паламарчук К. М. Творчість Клопштока і духовна музика Австрії і Німеччини другої половини XVIII - початку XIX століть. Актуальні проблеми історії, теорії та практики художньої культури. 2011. № 27. С. 292-300.

9. Полтавський М. А. История Австрии: в 2 ч. Москва, 1992. Ч. 1. 443 с.

10. Пушнова Ю. Б. История мировых религий. Москва, 2005. 168 с.

11. РЕЛІГІЯ-СВІТ-УКРАЇНА. Колективна монографія в 3-х книгах. Книга 3: Релігійні процеси в перспективі їх виявів. I За наук. ред. А. Колодного і Л. Филипович. Київ, 2012. 550 с.

12. Річинський А. Всенародні співи в українській церкві. Збірка загально-доступних церковних співів для сільських хорів, для шкіл і народу. Володимир Волинський, 1925.

13. Тейлор А. Дж. П. Габсбурзька монархія 1809 - 1918. Історія Австрійської імперії та Австро-Угорщини. Львів, 2002. 268 c.

14. Цьольнер Е. Історія Австрії. Львів, 2001. 712 с.

15. Pfeiffer J. Dichtkunst und Kirchenlied. Über das geistlische Lied im Zeitalter. Hamburg, 1961. 204 p.

\section{References}

1. Vinter E. (1964). Josephism and Modernity. Problems of religion history and atheism,12,72-80 [in Russian].

2. Hrushevskyi M. C. (1994). History of Ukrainian literature. Kyiv: Lybid [in Ukrainian].

3. Zhalovaga A. S. (2008). Anthropological nature of Christianity. Kyiv [in Ukrainian]

4. Kartashev A. V. (1943). Church and nationality.Way, 44, 3-14 [in Russian].

5. Mitrofanov P. P. (2003). The history of Austria from the earliest times to 1792 year. Moscow: Editorial [in Russian].

6. Neretina S. S., Ogurtsov A. P. (2000) The time of culture. Saint Petersburg: Ateleya [in Russian].

7. Palamarchuk K. M. (2011). Catholic church art of Austria of the XVIII-XIX centuries: stylistic tendencies. Art-sculptures, $20,328-335$ [in Ukrainian].

8. Palamarchuk K. M. (2011). The art of Klopstock and the sacred music of Austria and Germany in the second half of the XVIII and the beginning of the XIX centuries. Current problems of the history, theory and practice of artistic culture, 27, $292-300$ [in Ukrainian].

9. Poltavsky M. A. (1992). History of Austria. Vol 1. Moscow: RAS [in Russian].

10. Pushnova Y. B. (2005). History of World Religions. Moscow: Vladpres [in Russian].

11. Kolodniy A., Philipovich L. (2012). Religion - world - Ukraine. Religious processes in terms of their expressions. Ukrainian religious studies. Kyiv: [N.p.] [in Ukrainian].

12. Richinsky A. (1925). National songs in the Ukrainian church. Collection of commonly available church chants for village choirs, for schools and people. Vladimir Volynsky [in Ukrainian].

13. Taylor A. J. P. (2002). Habsburg Monarchy 1809 - 1918. The History of the Austrian Empire and Austro-Hungary. Lviv: VNTL-Classic [in Ukrainian].

14. Tsolner E. (2001). Austrian history. Lviv: Chronicle [in Ukrainian].

15. Pfeiffer J. (1961). Dichtkunst und Kirchenlied. Über das geistlische Lied im Zeitalter. Hamburg : Wittig.

Стаття надійшла до редакції 26.11.2018 р.

УДК 316.77:355.488 (477)

Парфенюк Ігор Миколайович

кандидат наук із соціальних комунікацій,

декан фракультету журналістики

та міжнародних відносин

Київського університету культури

parfeniuk10@gmail.com

ORCID 0000-0001-6203-2356

\section{ТРАНСФОРМАЦІЯ КУЛЬТУРНИХ ЦІННОСТЕЙ В ЕПОХУ ІНФОРМАЦІЙНИХ ВІЙН}

Мета статті - з'ясувати специфіку трансформації культурних цінностей в епоху інформаційних війн. Методологія дослідження. Методом індукції на прикладі інформаційно-психологічних операцій та війн доведено ключову роль культури під час цілеспрямованого інформаційного впливу. Наукова новизна полягає у виявленні взаємозалежності між інформаційним та культурним простором під час стандартних і стратегічних інформаційних війн, а також обґрунтуванні положення про те, що інформаційний агресор, змінюючи інформаційний простір, поступово досягає змін у культурному. Висновки. Зміна культурних цінностей часто відбувається внаслідок ведення стратегічних інформаційних війн. Вплив на культуру, насамперед, пов'язаний із поширенням невибагливої масової культури з певним ідеологічним наповненням. Масова культура - ефективний інструмент інформаційної війни. Її переваги в тому, що вона не лише приносить прибуток і в найдоступнішій формі подає потрібну інформацію, а й усуває й замінює цінності національних культур, що робить об'єктів інформаційної агресії уразливими й слабкими. Продукти масової культури поширюються за допомогою ЗМІ, Інтернету, естради, літератури, кінематографа, комп'ютерних ігор тощо. Всі ці засоби мають велику популярність і є доступними для широких верств населення. За їхньою допомогою чужі культурні елементи інтегруються в культурне середовище об'єкта агресії, сприймаються як нові, «модні» й поступово замінюють або трансформують певні невигідні для суб'єктів інформаційного впливу культурні компоненти. Відповідно, зміни в культурі об'єкта інформаційного впливу відбуваються в залежності від змін у культурно-інформаційному просторі. Цілеспрямовані зміни в культурному середовищі об'єкта впливу дають можливість інформаційному агресору скоригувати усталені переконання, моделі поведінки, світогляд. Тому для захисту від інформаційних атак необхідно забезпечити функціонування ефективних способів захисту свого культурного простору, а саме: дієву законодавчу базу з потужними механізмами охорони культурних цінностей, постійний моніторинг та аналіз зовнішніх і внутрішніх інформаційно-комунікаційних джерел, створення позитивної репутації країни, сприяння виробництву й розвитку власного культурного продукту.

Ключові слова: інформаційні війни; культура; культурні цінності; трансформація.

Парфенюк Игорь Николаевич, кандидат наук по социальным коммуникациям, декан фракультета журналистики и международных отношений Киевского университета культуры

(C) Парфенюк I.M., 2019 